\title{
An appraisal of Indonesia's immense peat carbon stock using national peatland maps: uncertainties and potential losses from conversion
}

\author{
Matthew Warren ${ }^{1 *} \mathbb{0}$, Kristell Hergoualc' $h^{2}$, J. Boone Kauffman ${ }^{3,4}$, Daniel Murdiyarso ${ }^{3,5}$ and Randall Kolka ${ }^{6}$
}

\begin{abstract}
Background: A large proportion of the world's tropical peatlands occur in Indonesia where rapid conversion and associated losses of carbon, biodiversity and ecosystem services have brought peatland management to the forefront of Indonesia's climate mitigation efforts. We evaluated peat volume from two commonly referenced maps of peat distribution and depth published by Wetlands International (WI) and the Indonesian Ministry of Agriculture (MoA), and used regionally specific values of carbon density to calculate carbon stocks.

Results: Peatland extent and volume published in the MoA maps are lower than those in the WI maps, resulting in lower estimates of carbon storage. We estimate Indonesia's total peat carbon store to be within $13.6 \mathrm{GtC}$ (the low MoA map estimate) and $40.5 \mathrm{GtC}$ (the high WI map estimate) with a best estimate of $28.1 \mathrm{GtC}$ : the midpoint of medium carbon stock estimates derived from WI (30.8 GtC) and MoA (25.3 GtC) maps. This estimate is about half of previous assessments which used an assumed average value of peat thickness for all Indonesian peatlands, and revises the current global tropical peat carbon pool to $75 \mathrm{GtC}$. Yet, these results do not diminish the significance of Indonesia's peatlands, which store an estimated 30\% more carbon than the biomass of all Indonesian forests. The largest discrepancy between maps is for the Papua province, which accounts for $62-71 \%$ of the overall differences in peat area, volume and carbon storage. According to the MoA map, $80 \%$ of Indonesian peatlands are $<300 \mathrm{~cm}$ thick and thus vulnerable to conversion outside of protected areas according to environmental regulations. The carbon contained in these shallower peatlands is conservatively estimated to be $10.6 \mathrm{GtC}$, equivalent to $42 \%$ of Indonesia's total peat carbon and about 12 years of global emissions from land use change at current rates.
\end{abstract}

Conclusions: Considering the high uncertainties in peatland extent, volume and carbon storage revealed in this assessment of current maps, a systematic revision of Indonesia's peat maps to produce a single geospatial reference that is universally accepted would improve national peat carbon storage estimates and greatly benefit carbon cycle research, land use management and spatial planning.

Keywords: Tropical peatlands, Wetlands, Climate change mitigation, Carbon pools, Carbon emissions, Peat degradation

\section{Background}

Tropical peatlands are known to be globally significant deposits of terrestrial organic carbon with estimates

\footnotetext{
*Correspondence: mwwarren@fs.fed.us; mwwarren.usfs@gmail.com 1 USDA Forest Service, Northern Research Station, 271 Mast Rd., Durham, $\mathrm{NH} 03824$, USA
}

Full list of author information is available at the end of the article ranging from 50 [1] to $105 \mathrm{GtC}$ [2, 3]; equivalent to about $15 \%$ of carbon stored in peat globally. Peatlands occur throughout the tropics, covering between 33.4 and 57.8 Mha. This maximum estimate includes the 13.6 Mha of additional peatland that was recently reported for the Central Congo Basin [2, 3]. Southeast Asia contains the largest proportion of tropical peatland 
with an estimated $41 \%$ of tropical peatland area and $65 \%$ of the tropical peat $\mathrm{C}$ store $(105 \mathrm{GtC})[2,3]$. Indonesia alone contains approximately $36 \%$ of the world's tropical peatlands with frequently cited estimates of about 21 Mha (RePPProt [4], cited in Page et al. [2, 5-7]). Peatlands in Southeast Asia have formed over thousands of years with the oldest initiating around 20,000 years ago in the upper Kapuas Basin of West Kalimantan, Indonesia [8]. However, most peatlands in Southeast Asia are less than 7000 years old [9]. Forested ombrotrophic peat swamps have developed in landscapes where abundant precipitation and low relief produce high water tables and frequent inundation. These conditions are characteristic of the wide, low lying interfluves on the coastal plains of Sumatra, Borneo and Papua. Saturated peat soils are anoxic and nutrient poor, which impedes full decomposition of forest litter. Consequently, small amounts of residual organic matter accumulate and cause accretion of the peat layer [9-11].

Peat swamps in Sumatra and Kalimantan (Indonesian Borneo) have been large and persistent carbon sinks from around 15,000 years ago to present, sequestering between 0.5 and $1.5 \mathrm{Mg} \mathrm{C} / \mathrm{ha}^{1}$ year $^{-1}$ in peat $[9,12]$. Although peat accumulation rates are only about $0.2-2.0 \mathrm{~mm}_{\text {year }}{ }^{-1}$, deposits up to several meters thick have formed over millennia, resulting in dense soil organic carbon pools that are stabilized by permanent anoxic conditions in the saturated peat profile $[9,12]$. The resulting peat carbon stores are often in excess of $1000 \mathrm{Mg} \mathrm{C} / \mathrm{ha}^{1}$ with values over $7500 \mathrm{Mg} \mathrm{C} / \mathrm{ha}^{1}$ reported for exceptionally thick ( $>12 \mathrm{~m}$ ) peat layers [13-15]. These carbon stores per area are immense compared to the average amount of carbon in the above-ground biomass of mature tropical rainforest, typically $130-240 \mathrm{Mg} \mathrm{C} / \mathrm{ha}^{1}[16]$.

In addition to carbon sequestration, Indonesian peat swamp forests supply many ecological benefits to large coastal populations living in and around peatland landscapes. Peat swamp forests have been historical sources of timber and non-timber forest products including food, fiber, latex, medicine and materials for household goods. Peat swamps regulate hydrology by mitigating floods during wet seasons and intense rainfall events, and maintain base flows in streams and rivers during dry periods by slowly releasing stored water. Peat forests are also high in biodiversity and are critical habitat for many rare and endangered species including Sumatran tigers, orangutans, gibbons, and leopards [17-20]. Despite these values, Indonesian peat swamp forests are being deforested, drained and converted at unprecedented rates [21-23]. For example, Miettinen et al. [24] reported a 41.3\% loss in peat swamp forest cover in Sumatra, and a 24.8\% loss for the whole island of Borneo from 2000 to 2010. Trends in peatland conversion have continued with only $29 \%$ of peatlands remaining forested in Peninsular Malaysia, Borneo and Sumatra in 2015 [25]. Deforested peatlands are generally converted to industrial and smallholder plantations including oil palm (Elaeis guineensis) and acacia (Acacia spp.) for pulp and paper production. Miettinen et al. [25] estimated about $23,000 \mathrm{~km}^{2}$ of peat swamp forest were converted into industrial plantations by 2010 throughout Sumatra and the Kalimantan provinces of Indonesian Borneo.

Peat swamp conversion requires extensive drainage, and fire is often used to open land and remove undesired biomass to prepare for planting. Both of these activities cause large-scale greenhouse gas (GHG) emissions to the atmosphere $[10,26]$ which is the cause of major international concern. Drainage releases aerobic microbes from physiologically constraining anoxic conditions, resulting in rapid decomposition and heterotrophic $\mathrm{CO}_{2}$ production [27]. Decomposition may be further accelerated by additions of chemical fertilizers [28-30]. Net peat $\mathrm{CO}_{2}$ emissions are estimated to be 296 and $125 \mathrm{Mg} \mathrm{CO}_{2}-\mathrm{C} /$ $\mathrm{ha}^{1}$ for oil palm and Acacia plantations, over respective rotation periods of 25 and 6 years [31]. The IPCC guidelines [31] suggest an additional $88 \mathrm{Mg} \mathrm{C} / \mathrm{ha}^{1}$ lost to the atmosphere from each land-clearing peat fire. Total (from peat and vegetation) carbon emissions from peat forest conversion to oil palm plantation are estimated to be between 350 and $487 \mathrm{Mg} \mathrm{C} / \mathrm{ha}^{1}$ over a 25 year crop rotation $[10,31,32]$. These estimates are conservative since they exclude on-site non- $\mathrm{CO}_{2}$ GHG emissions, including $\mathrm{CH}_{4}$ emissions from drainage ditches, and $\mathrm{N}_{2} \mathrm{O}$ emissions from peat decomposition and application of nitrogenous fertilizers [31]. Per unit area, GHG emissions from tropical peatland conversion are higher than those from any other land use, land use change and forestry (LULUCF) activity. As a result, fire and peat emissions are Indonesia's largest source of GHG (about $38 \%$ of total national emissions) and place Indonesia among the top five GHG emitting countries [33, 34]. Indonesia's climate change mitigation efforts are therefore oriented towards avoiding GHG emissions from peatlands through conservation and restoration activities (e.g. REDD+).

From a national standpoint, quantifying Indonesia's peatland carbon assets and associated uncertainties is critical for carbon valuation on emerging compliance and voluntary markets. Improving estimates of Indonesia's peatland carbon store also has global implications: they are currently estimated to comprise $64 \%$ of the total tropical peat carbon pool [2]. There are several estimates of Indonesia's peatland carbon store either regionally or nationwide (see Wahyunto et al. [2, 5-7, 13, 35]). However, only Wahyunto et al. [5-7] provide a national carbon storage estimate based on maps of peat distribution, thickness, and carbon density for Sumatra, Kalimantan 
and Papua islands. Here we revisit Indonesian peat carbon stores and their uncertainty using two current maps of peat area and thickness to calculate peat volume, and geographically specific peat carbon densities to calculate carbon mass.

\section{Indonesia peat map sources}

We considered the two commonly used geospatial references for the extent and depth of Indonesian peatlands: (1) Maps of Indonesian peat distribution and carbon content published by Wetlands International and Wildlife Habitat Canada (hereafter referred to as WI maps; [5-7]) and (2) The Indonesia peatlands map published by the Center for Research and Development of Agricultural Land Resources, Agricultural Research and Development Agency, Indonesia Ministry of Agriculture (hereafter referred to as the MoA map; [36]).

The WI maps are widely used for research, and are reference data layers of peatland distribution in recent analyses of land-use change [22-25, 37-39], fire emissions from peatlands $[26,40]$, land cover mapping [23, 39], and geological history of peat formation [35]. These maps were produced using source data from the Land Resource Evaluation and Planning Project (LREP), implemented by several Indonesian government agencies from 1985 to 1990; secondary field data obtained from the Bogor Agriculture and Land Research Center; source data from Land Form Classification Maps produced by the Regional Planning Program for Transmigration [40], and analysis of Landsat satellite imagery acquired in 1990 and 2002 [5-7]. The WI maps estimate the total peatland area of Indonesia to be 20,949,043 ha.

The MoA map is the official government map of peatlands in Indonesia. It is used by government agencies as a reference for spatial planning, land management decisions and estimates of peat land use, and land use change. It is based on several preceding peatland and soil maps of Indonesia, including the WI maps. Data sources include LREP data and RePPProt Land Form Classification maps [4], similar to WI maps [36]. In addition, data from several regional land and soil surveys provided by Haryono et al. [36] contributed to its development. MoA maps estimate the total peatland area of Indonesia to be 14,905,575 ha.

Page et al's [2] global assessment of tropical peatland area and carbon storage used another older map, the Land Form Classification Maps produced by the Regional Planning Program for Transmigration [4] for the extent and distribution of Indonesian peatlands. The program used a land system approach to classify Indonesian landforms and includes eight peatland categories. The maps indicate that Indonesia's peatlands cover approximately
20,000,000 ha. These maps were produced from interpretation of aerial photography and Landsat satellite imagery in areas that lacked coverage. Although the landform maps imply "shallow" and "deep" peatlands, depth intervals are not provided, so these maps cannot be compared to the WI or MoA sources and are not included in the current analysis. In addition, the maps are less readily available and are used as a reference, rather than a national standard for spatial planning, management, or policy decisions regarding peatlands.

\section{Map comparisons}

Direct detection of peat and continuous measurement of its thickness cannot be reliably accomplished using current remote sensing technology unless suitable vegetation proxies are available [41]. Much of Indonesia's peatlands have undergone anthropogenic alteration or conversion, confounding peatland delineation by forest canopy characteristics or surface moisture content measured via satellite. Therefore, the WI and MoA maps rely on few, widely dispersed and geographically biased field measurements of peat presence and thickness. Each map reports peat depth as intervals, and depth classes are inconsistent. The WI map includes depth classes of $50-100,100-200,200-400$, and $400-800 \mathrm{~cm}$ for Sumatran provinces [5]; <50, 50-100, 100-200, 200-400, $400-800$ and $800-1200 \mathrm{~cm}$ for the Kalimantan provinces [6]; and <50, 50-100, 100-200 and 200-300 cm for Papuan provinces [7]. The MoA maps report standard peat depth intervals: $50-100,100-200,200-300$, and $>300 \mathrm{~cm}$ for all provinces [36]. We calculated peat area, volume, and carbon stores for each depth class, aggregated them across all depths, and compared results from each map source. Area, volume, and carbon storage of peat layers deeper than $200 \mathrm{~cm}$ were combined into a single category $(>200 \mathrm{~cm})$. To allow for comparison with the MoA map, the Irian Jaya Timur and Papua provinces reported in WI maps were merged, consistent with provincial boundaries established by the Indonesian government in 2003.

\section{Carbon storage}

Peat carbon storage was calculated as:

$$
\mathrm{C}_{\text {peat }}=\mathrm{V} * \mathrm{C}_{\mathrm{d}}
$$

where $\mathrm{C}_{\text {peat }}$ is carbon storage $(\mathrm{kg} \mathrm{C}) ; \mathrm{V}$ is peat volume $\left(\mathrm{m}^{3}\right)$ and $\mathrm{C}_{\mathrm{d}}$ is peat carbon density $\left(\mathrm{kg} \mathrm{C} / \mathrm{m}^{3}\right)$, the product of bulk density $\left(\mathrm{kg} / \mathrm{m}^{3}\right)$ and carbon content $(\% \mathrm{C})$. When possible, regionally specific $C_{d}$ values were used to calculate carbon storage by province. Carbon density data were compiled from peer reviewed literature and previous reviews (Table 1 ). Only data with $\% \mathrm{C}$ values determined by elemental analysis using induction furnace 


\begin{tabular}{|c|c|c|}
\hline Province & $C_{d}$ & Sources \\
\hline West Kalimantan & 55.5 & $\begin{array}{l}\text { Neuzil [44], Anshari et al. [45], Warren et al. } \\
\text { [15] }\end{array}$ \\
\hline Central Kalimantan & 61.6 & Neuzil [44], Page et al. [46], Warren et al. [15] \\
\hline South Kalimantan & 61.6 & Regional Central Kalimantan value used. \\
\hline East Kalimantan & 65.1 & Average literature value \\
\hline Aceh Darussalam & 65.1 & \\
\hline Bangka Belitung & 65.1 & \\
\hline Bengkulu & 65.1 & \\
\hline Jambi & 54.5 & Warren et al. [15] \\
\hline Lampung & 65.1 & Average literature value \\
\hline Riau & 69.8 & Brady [47], Neuzil [44] \\
\hline West Sumatra & 65.1 & Average literature value \\
\hline South Sumatra & 65.1 & \\
\hline North Sumatra & 65.1 & \\
\hline Papua & 65.1 & \\
\hline West Papua & 65.1 & \\
\hline
\end{tabular}

Average $C_{d}$ from all listed sources was used for provinces absent from published literature

methods were included. Carbon density calculated from default values or $\% \mathrm{C}$ determined by semi-quantitative methods such as Walkely-Black wet combustion or loss on ignition (LOI) have been shown to be less reliable for highly organic soils $[42,43]$.

Since peat depth is reported on an interval scale, we calculated a low, medium, and high estimate for each map. Low estimates assumed all peatlands within each depth class were at the low end of the depth class. For example, a depth of $100 \mathrm{~cm}$ was used for all peatlands within the $100-200 \mathrm{~cm}$ class. Medium estimates assumed the depth of all peatlands within a given class were at the midpoint (i.e. $150 \mathrm{~cm}$ used for the $100-200 \mathrm{~cm}$ depth class), and high estimates assumed all peatlands within a given depth class were the highest end of the class (i.e. $200 \mathrm{~cm}$ used for the 100-200 cm interval). The WI maps also report peatlands $<50 \mathrm{~cm}$, therefore values of 10,25 and $50 \mathrm{~cm}$ were used for low, medium and high volume estimates for that depth class. In the $>200 \mathrm{~cm}$ depth class values of 300,750 , and 1000 were used for low, medium and high estimates respectively. The low estimate, $300 \mathrm{~cm}$, is the upper end of depth reported by the MoA maps; the high estimate is the midpoint of the 800$1200 \mathrm{~cm}$ deepest depth class used in the WI maps (Kalimantan) and the medium estimate is the midpoint of the $300 \mathrm{~cm}$ minimum and $1200 \mathrm{~cm}$ maximum reported for the deepest depth class in the MoA and WI (Kalimantan) maps respectively. Best estimates of peat $C$ storage were obtained by averaging the medium $\mathrm{C}$ stock estimates for each map.

\section{Results}

\section{Peatland distribution and depth}

The WI maps report 20,949,043 ha of peatlands distributed throughout four provinces in Kalimantan (Borneo), nine provinces in Sumatra, and three provinces in Papua (Table 2). Provinces containing the largest area of peatlands include Papua (27\%), Riau, (19\%) and Central Kalimantan (14\%). The maps indicate that about $83 \%$ of Indonesian peatlands are less than $4 \mathrm{~m}$ deep. The distribution of peatlands in each depth class differs among Papua, Sumatra, and Kalimantan. Peatlands in Papua are assigned to shallower depths: $67 \%$ are within the $50-100 \mathrm{~cm}$ depth class, about $22 \%$ are within the 200-300 cm depth class, and no peatlands are mapped to be deeper than $300 \mathrm{~cm}$. In contrast, $31 \%$ of peatlands in Sumatra are mapped $>400 \mathrm{~cm}$ deep, $64 \%$ are within the $100-400 \mathrm{~cm}$ depth, and only about $5 \%$ are in the $50-100 \mathrm{~cm}$ depth class.

The MoA maps indicate 14,905,575 ha of peatlands distributed throughout four provinces in Kalimantan, ten provinces in Sumatra, and two provinces in Papua (Table 3). Contrary to the WI maps, Sumatra contains the largest peatland area (43\%), followed by Kalimantan (32\%) and Papua (25\%). The MoA maps indicate that about $80 \%$ of peatlands are $<300 \mathrm{~cm}$ deep. Similar to the WI maps, peatland distribution across depth classes differs among islands. Consistent with WI maps, no peatlands are mapped to be $>300 \mathrm{~cm}$ deep in Papua. In Sumatra, peatlands are distributed more evenly across size classes with $50-100,100-200$, and $>300 \mathrm{~cm}$ depth classes containing $27 \%$ of the peatland area each, and the 200-300 cm depth class accounting for the remaining $19 \%$. Peatlands in Kalimantan are also distributed more evenly, with the 50-100, 100-200, 200-300 and $>300 \mathrm{~cm}$ depth classes containing $22,29,22,27 \%$ of mapped peatlands, respectively.

There are 6,043,468 fewer hectares of peatland delineated on the MoA maps than on the WI maps (Table 4; Additional file 1: Tables 1-5). The MoA maps report less peatlands in all provinces except West Papua. However, the main difference $(4,356,800 \mathrm{ha})$ between the MoA and WI maps is located in the Papua province, representing $71 \%$ of the total $6,115,734$ fewer hectares of peatlands delineated across all provinces except West Papua. The second largest difference between maps is for Kalimantan provinces $(991,241 \mathrm{ha})$, together accounting for $16 \%$ of the total difference, followed by Sumatran provinces $(767,693)$, representing about $13 \%$ of the total difference between maps. Less peatland area on the MoA maps results from large reductions in deeper size classes which are not offset by gains in shallower size classes. For example in South Sumatra, there are 796,814 fewer hectares in depth classes $>100 \mathrm{~cm}$, and 639,156 more hectares 
Table 2 Peat area (ha) by province and depth class published in the WI maps

\begin{tabular}{|c|c|c|c|c|c|c|c|c|}
\hline \multirow[t]{2}{*}{ Province } & \multicolumn{6}{|c|}{ Depth classes } & \multirow[t]{2}{*}{ Total area } & \multirow[t]{2}{*}{$\%$} \\
\hline & $<50 \mathrm{~cm}$ & $50-100 \mathrm{~cm}$ & $100-200 \mathrm{~cm}$ & $200-400 \mathrm{~cm}$ & $400-800 \mathrm{~cm}$ & $800-1200 \mathrm{~cm}$ & & \\
\hline West Kalimantan & 36,673 & 438,172 & 737,111 & 213,705 & 304,319 & & $1,729,980$ & 8 \\
\hline Central Kalimantan & 75,990 & 958,486 & 462,399 & 574,978 & 661,093 & 277,694 & $3,010,640$ & 14 \\
\hline South Kalimantan & 76,785 & 79,368 & 78,766 & 96,710 & - & & 331,629 & 2 \\
\hline East Kalimantan & & 264,559 & 112,511 & 219,703 & 100,224 & - & 696,997 & 3 \\
\hline Kalimantan total & 189,448 & $1,740,585$ & $1,390,787$ & $1,105,096$ & $1,065,636$ & 277,694 & $5,769,246$ & 28 \\
\hline Aceh & - & 2219 & 175,558 & 96,274 & - & - & 274,051 & 1 \\
\hline Bangka Belitung & - & - & 54,724 & 8896 & - & - & 63,620 & 0 \\
\hline Bengkulu & - & 3588 & 37,317 & 20,082 & 2066 & - & 63,053 & 0 \\
\hline Jambi & - & 92,520 & 207,621 & 316,305 & 100,392 & - & 716,838 & 3 \\
\hline Lampung & - & - & 87,567 & - & - & - & 87,567 & 0 \\
\hline Riau & - & 76,194 & $1,324,426$ & 575,343 & $2,067,638$ & - & $4,043,601$ & 19 \\
\hline West Sumatra & - & 89,353 & 42,817 & 22,199 & 55,865 & - & 210,234 & 1 \\
\hline South Sumatra & - & 66,201 & $1,308,832$ & 45,009 & - & - & $1,420,042$ & 7 \\
\hline North Sumatra & - & 47,212 & 228,424 & 49,700 & - & - & 325,336 & 2 \\
\hline Sumatra total & - & 377,287 & $3,467,286$ & $1,133,808$ & $2,225,961$ & - & $7,204,342$ & 34 \\
\hline Papua & 180,493 & $3,701,845$ & 701,237 & $1,106,417$ & - & - & $5,689,992$ & 27 \\
\hline West Irian Jaya & - & 844,442 & - & 129,775 & - & - & 974,217 & 5 \\
\hline East Irian Jaya & - & 830,093 & - & 481,153 & - & - & $1,311,246$ & 6 \\
\hline Papua total & 180,493 & $5,376,380$ & 701,237 & $1,717,345$ & - & - & $7,975,455$ & 38 \\
\hline Total & 369,941 & $7,494,252$ & $5,559,310$ & $3,956,249$ & $3,291,597$ & 277,694 & $20,949,043$ & 100 \\
\hline$\%$ & 2 & 36 & 27 & 19 & 16 & 1 & 100 & \\
\hline
\end{tabular}

For Papua provinces a $200-300 \mathrm{~cm}$ depth class is reported

in the $50-100 \mathrm{~cm}$ depth class on the MoA map, resulting in a net difference of 157,658 ha for the province. For depth classes $>200 \mathrm{~cm}$, net differences are negative for all provinces except Central Kalimantan where the MoA map indicates 64,449 ha more peatlands than the WI map. However, 462,104 ha fewer peatlands in depth classes $<100 \mathrm{~cm}$ offset gains in classes $>100 \mathrm{~cm}$, resulting in 351,406 ha fewer peatlands in Central Kalimantan on the MoA map.

\section{Peat volume}

The smaller area of peatlands delineated on the MoA than on the WI maps, particularly in depth classes $>200 \mathrm{~cm}$, results in lower peat volume estimates (Table 5). Low, medium and high estimates of total peat volume for the WI maps are: 298,476 , and $643 \mathrm{~km}^{3}$, respectively, whereas for MoA maps they are 210, 391, and $519 \mathrm{~km}^{3}$, respectively (Additional file 1: Tables $6-10$ ). Overall, the difference in medium peat volume estimates between maps is $85 \mathrm{~km}^{3}$. The largest difference is for Papua and is due to dissimilarities in peat area in depth classes $50-100 \mathrm{~cm}$ and $>200 \mathrm{~cm}$ in Papua province. In total, Papuan provinces represent $62 \%$ of the peat volume difference between maps. Large gaps are also found for Sumatra $\left(24 \mathrm{~km}^{3}\right)$, especially for South Sumatra $\left(7 \mathrm{~km}^{3}\right)$,
Jambi $\left(5 \mathrm{~km}^{3}\right)$ and Aceh Darussalem $\left(3 \mathrm{~km}^{3}\right)$. In Kalimantan, discrepancies between maps are mainly for East Kalimantan, where there is $5 \mathrm{~km}^{3}$ less peat volume on the MoA than on the WI maps.

\section{Peat carbon}

Differences in peat carbon storage estimates between the MoA and WI maps reflect observed differences in peat volumes. Low, medium and high estimates of peat carbon storage for the WI maps are 19.23, 30.79 and $40.49 \mathrm{GtC}$, respectively (Table 6); and are 13.56, 25.33, and $33.77 \mathrm{GtC}$, for the MoA map, respectively (Table 7). The difference between medium peat carbon estimates is $5.46 \mathrm{GtC}$ in total (Table 8; Additional file 1: Tables 11-19) and is mainly concentrated in Papua accounting for about $63 \%$ of the overall difference. In that province high discrepancies of 1.48 and $2.06 \mathrm{GtC}$ are noticeable in the $50-100 \mathrm{~cm}$ and $>200 \mathrm{~cm}$ depth classes. In Sumatra the difference between maps $(1.49 \mathrm{GtC})$ is mostly located in South Sumatra $(0.48 \mathrm{GtC})$, Jambi $(0.26 \mathrm{GtC})$, and Aceh Darussalam (0.22 GtC). Finally, in Kalimantan most of the dissimilarity $(0.55 \mathrm{GtC})$ relates to East Kalimantan (0.35 GtC).

Depth classes $>200 \mathrm{~cm}$ contain approximately 71 and $75 \%$ of Indonesia's peat carbon according to the WI and 
Table 3 Peat Area (ha) by province and depth class published in the MoA maps

\begin{tabular}{|c|c|c|c|c|c|c|}
\hline \multirow[t]{2}{*}{ Province } & \multicolumn{4}{|l|}{ Depth class } & \multirow[t]{2}{*}{ Total area } & \multirow[t]{2}{*}{$\%$} \\
\hline & $50-100 \mathrm{~cm}$ & $100-200 \mathrm{~cm}$ & $200-300 \mathrm{~cm}$ & $>300 \mathrm{~cm}$ & & \\
\hline West Kalimantan & 421,697 & 818,460 & 192,988 & 246,989 & $1,680,134$ & 11 \\
\hline Central Kalimantan & 572,372 & 508,648 & 632,989 & 945,225 & $2,659,234$ & 18 \\
\hline South Kalimantan & 10,185 & 21,124 & 74,962 & - & 106,271 & 1 \\
\hline East Kalimantan & 44,357 & 41,582 & 171,830 & 74,597 & 332,366 & 2 \\
\hline Kalimantan total & $1,048,611$ & $1,389,814$ & $1,072,769$ & $1,266,811$ & $4,778,005$ & 32 \\
\hline Aceh Darussalam & 144,274 & 71,430 & - & - & 215,704 & . \\
\hline Bangka Belitung & 42,568 & - & - & - & 42,568 & c \\
\hline Bengkulu & 3856 & 802 & 2451 & 944 & 8053 & 0 \\
\hline Jambi & 91,816 & 142,716 & 345,811 & 40,746 & 621,089 & 4 \\
\hline Kepulauan Riau & 103 & 8083 & - & - & 8186 & 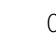 \\
\hline Lampung & 49,331 & - & - & - & 49,331 & 0 \\
\hline Riau & 509,209 & 908,553 & 838,538 & $1,611,114$ & $3,867,414$ & 26 \\
\hline West Sumatra & 11,454 & 24,370 & 14,533 & 50,329 & 100,686 & 1 \\
\hline South Sumatra & 705,357 & 515,400 & 41,627 & - & $1,262,384$ & 8 \\
\hline North Sumatra & 209,335 & 36,472 & - & 15,427 & 261,234 & 2 \\
\hline Sumatra total & $1,767,303$ & $1,707,826$ & $1,242,960$ & $1,718,560$ & $6,436,649$ & 43 \\
\hline Papua & $1,506,913$ & 817,651 & 319,874 & $1,718,560$ & $2,644,438$ & 18 \\
\hline Papua Barat & 918,610 & - & 127,873 & - & $1,046,483$ & 7 \\
\hline Papua total & $2,425,523$ & 817,651 & 447,747 & - & $3,690,921$ & 25 \\
\hline Total & $5,241,437$ & $3,915,291$ & $2,763,476$ & $2,985,371$ & $14,905,575$ & 100 \\
\hline$\%$ & 35 & 26 & 19 & 20 & 100 & \\
\hline
\end{tabular}

Table 4 Difference in peat area between MoA and WI maps ( Area $\left._{\text {MoA }}-A^{-} a_{W I}\right)$ by province and depth class

\begin{tabular}{|c|c|c|c|c|c|c|}
\hline \multirow[t]{2}{*}{ Province } & \multicolumn{4}{|c|}{ Depth class } & \multirow[t]{2}{*}{ Total area } & \multirow[t]{2}{*}{$\%$} \\
\hline & $<50 \mathrm{~cm}$ & $50-100 \mathrm{~cm}$ & $100-200 \mathrm{~cm}$ & $>200 \mathrm{~cm}$ & & \\
\hline West Kalimantan & $-36,673$ & $-16,475$ & 81,349 & $-78,047$ & $-49,846$ & 1 \\
\hline Central Kalimantan & $-75,990$ & $-386,114$ & 46,249 & 64,449 & $-351,406$ & 6 \\
\hline South Kalimantan & $-76,785$ & $-69,183$ & $-57,642$ & $-21,748$ & $-225,358$ & 4 \\
\hline East Kalimantan & - & $-220,202$ & $-70,929$ & $-73,500$ & $-364,631$ & 6 \\
\hline Kalimantan total & $-189,448$ & $-691,974$ & -973 & $-108,846$ & $-991,241$ & 16 \\
\hline Aceh & - & 142,055 & $-104,128$ & $-96,274$ & $-58,347$ & 1 \\
\hline Bangka Belitung & - & 42,568 & $-54,724$ & -8896 & $-21,052$ & 0 \\
\hline Bengkulu & - & 268 & $-36,515$ & $-18,753$ & $-55,000$ & 1 \\
\hline Jambi & - & -704 & $-64,905$ & $-30,140$ & $-95,749$ & 2 \\
\hline Lampung & - & 49,331 & $-87,567$ & - & $-38,236$ & 1 \\
\hline Riau & - & 433,118 & $-407,790$ & $-193,329$ & $-168,001$ & 3 \\
\hline West Sumatra & - & $-77,899$ & $-18,447$ & $-13,202$ & $-109,548$ & 2 \\
\hline South Sumatra & - & 639,156 & $-793,432$ & -3382 & $-157,658$ & 3 \\
\hline North Sumatra & - & 162,123 & $-191,952$ & $-34,273$ & $-64,102$ & 1 \\
\hline Sumatra total & - & 1,390,016 & $-1,759,460$ & $-398,249$ & $-767,693$ & 13 \\
\hline Papua & $-180,493$ & $-3,025,025$ & 116,414 & $-1,267,696$ & $-4,356,800$ & 72 \\
\hline West Papua & - & 74,168 & - & -1902 & 72,266 & 1 \\
\hline Papua total & $-180,493$ & $-2,950,857$ & 116,414 & $-1,269,598$ & $-4,284,534$ & 71 \\
\hline Total & $-369,941$ & $-2,302,146$ & $-1,644,019$ & $-1,776,693$ & $-6,043,468$ & 100 \\
\hline$\%$ & 6 & 38 & 27 & 29 & 100 & \\
\hline
\end{tabular}

Depth classes $>200 \mathrm{~cm}$ were combined to allow comparison 
Table 5 Medium estimates of peat volume $\left(\mathrm{km}^{3}\right)$ calculated from MoA and (WI) maps, and differences between map sources

\begin{tabular}{|c|c|c|c|c|c|c|c|c|c|c|c|c|c|c|c|}
\hline \multirow[t]{3}{*}{ Island } & \multicolumn{15}{|c|}{ Depth classes } \\
\hline & \multicolumn{3}{|c|}{$<50 \mathrm{~cm}$} & \multicolumn{3}{|c|}{$50-100 \mathrm{~cm}$} & \multicolumn{3}{|c|}{$100-200 \mathrm{~cm}$} & \multicolumn{3}{|c|}{$>200 \mathrm{~cm}$} & \multicolumn{3}{|l|}{ Total } \\
\hline & MoA & WI & Diff & MoA & WI & Diff & MoA & WI & Diff & MoA & WI & Diff & MoA & WI & Diff \\
\hline Kalimantan & - & 0.47 & -0.47 & 7.86 & 13.05 & -5.19 & 20.85 & 20.86 & -0.01 & 121.83 & 124.86 & -3.03 & 150.54 & 159.25 & -8.71 \\
\hline Sumatra & - & - & 0.00 & 13.25 & 2.83 & 10.43 & 25.62 & 52.01 & -26.39 & 159.97 & 167.57 & -7.61 & 198.84 & 222.41 & -23.57 \\
\hline Papua & - & 0.45 & -0.45 & 18.19 & 40.32 & -22.13 & 12.26 & 10.52 & 1.75 & 11.19 & 42.93 & -31.74 & 41.65 & 94.23 & -52.58 \\
\hline Total & - & 0.92 & -0.92 & 39.31 & 56.21 & -16.90 & 58.73 & 83.39 & -24.66 & 292.99 & 335.37 & -42.38 & 391.03 & 475.89 & -84.86 \\
\hline
\end{tabular}

Detailed low, medium and high estimates of peat volume by province and depth class are provided in Additional file 1:Tables 6-10

MoA maps, respectively. MoA maps indicate that about $58 \%(14.68 \mathrm{GtC})$ of peat carbon is contained in peatlands $>300 \mathrm{~cm}$ deep, and the remaining $42 \%(10.64 \mathrm{GtC})$ is in depth classes $<300 \mathrm{~cm}$. Similarly, $14.77 \mathrm{GtC}$ are estimated in depth classes $>400 \mathrm{~cm}$ on the WI maps; about $48 \%$ of the $30.79 \mathrm{GtC}$ medium estimate. The $5.46 \mathrm{GtC}$ difference in medium carbon storage estimates is distributed similarly across depth classes: there is a $2.76 \mathrm{GtC}$ difference for depth classes $<200 \mathrm{~cm}$ and a $2.70 \mathrm{GtC}$ difference for depth classes $>200 \mathrm{~cm}$.

\section{Discussion}

Indonesia's peat $C$ store is often cited as $57 \mathrm{GtC}$, the value reported by Page et al. [2] in their assessment of global tropical peat $C$ pools. Similarly, Jaenicke et al. [13] estimated Indonesia's peat carbon to be about $55 \mathrm{GtC}$. These results are in contrast with the $50 \mathrm{GtC}$ stored in all tropical peatlands reported by $\mathrm{Yu}$ et al. [1]. The medium estimates of 25.3 and $30.8 \mathrm{GtC}$ obtained from the MoA and WI maps (respectively) are substantially lower than those of Page et al. [2] and Jaenicke et al. [13] but are closer to the cumulative total of Wahyunto et al's [5-7] values available for the WI maps (37.2 GtC).

There is no current information to support or refute the validity of either map, as the accuracies of each map reflect the geographic bias of source data and field surveys, and neither map source provide quantitative estimates of uncertainty for peat volumes. Therefore we suggest a best estimate of Indonesian peat carbon of $28.1 \mathrm{GtC}$, the midpoint of the medium estimates of the two map sources. The broad range in carbon storage estimates are mainly caused by differences in peat volume among studies. Page et al. [2] estimated the peat volume to be $1138.2 \mathrm{~km}^{3}$, which was calculated assuming an average peat depth of $5.5 \mathrm{~m}$ across $206,950 \mathrm{~km}^{2}$ of peatland. Similarly, Jaenicke et al. [13] assumed an average peat depth of $4.5 \mathrm{~m}$ over $211,000 \mathrm{~km}^{2}$ of peatland, estimating the peat volume to be $949.5 \mathrm{~km}^{3}$. These peat volumes are about double our $475.89 \mathrm{~km}^{3}$ peat volume based on the midpoints of each depth interval multiplied by their spatial extent using WI maps (total area 209,490 $\mathrm{km}^{2}$ ).

Compared to national peat maps, the average peat depths used by Page et al. [2] and Jaenicke et al. [13] seem overestimated, as the average depth weighted to the upper bounds of each depth interval is about $3.1 \mathrm{~m}$ according to WI maps. A recent report by Hooijer and Vernimmen [48] suggested that both WI and MoA peat maps could consistently underestimate peat extent and peat thickness by 27 and 13\%, respectively. However, these results must be interpreted cautiously because the data used to support them violate assumptions of randomness and independence. In their study, the authors compiled a secondary dataset of peat thickness measurements to assess the accuracy of existing WI and MoA maps. The data are in fact not random, as existing peat thickness measurements were automatically taken on known peatlands. Therefore areas mapped as peatlands that are not actually peat are not represented in the data. In addition, spatially-dependent data were treated as independent in the analysis. Large sample sizes of peat thickness measurements were taken from peatland areas that are deeper than indicated on the maps, thus skewing the number of measurements where peatlands are underestimated on maps, and the total average peat depth. Finally, the Hooijer and Vernimmen [48] report does not include Papua provinces, which comprise the largest uncertainties in peat volume and extent, as reported here. Nevertheless, it is clear from the existing field data evaluated by Hooijer and Vernimmen [48] that peat thickness is underestimated on both WI and MoA maps over wide areas where data are available. It is beyond the scope of this study to compare the accuracies of each map without a random, independent, nationwide dataset necessary to make the assessment. Rather, we provide the most rigorous estimate of peat $\mathrm{C}$ stocks using the best information currently available.

Overall, peat carbon estimates range from $13.6 \mathrm{GtC}$ (the low MoA map estimate) to $40.5 \mathrm{GtC}$ (the high WI 


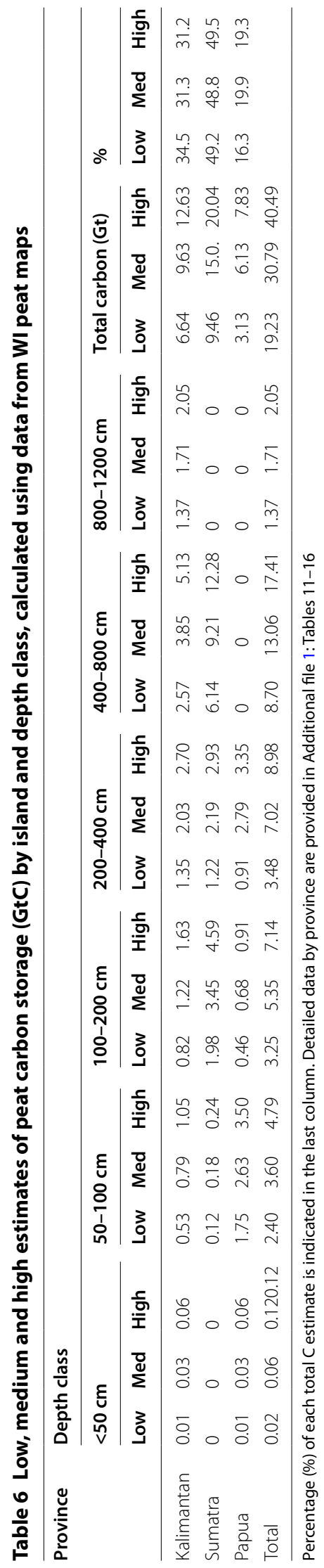


Table 7 Low, medium and high peat carbon storage (GtC) by island and depth class, calculated using data from MoA peat maps

\begin{tabular}{|c|c|c|c|c|c|c|c|c|c|c|c|c|c|c|c|c|c|c|}
\hline \multirow[t]{3}{*}{ Province } & \multicolumn{18}{|c|}{ Depth class } \\
\hline & \multicolumn{3}{|c|}{$50-100$} & \multicolumn{3}{|c|}{$100-200$} & \multicolumn{3}{|c|}{$200-300$} & \multicolumn{3}{|c|}{$>300$} & \multicolumn{3}{|c|}{ Total carbon (Gt) } & \multicolumn{3}{|l|}{$\%$} \\
\hline & Low & Med & High & Low & Med & High & Low & Med & High & Low & Med & High & Low & Med & High & Low & Med & High \\
\hline Kalimantan & 0.31 & 0.47 & 0.62 & 0.81 & 1.21 & 1.62 & 1.32 & 1.64 & 2.30 & 2.30 & 5.76 & 7.68 & 4.74 & 9.08 & 12.22 & 34.8 & 35.9 & 36.2 \\
\hline Sumatra & 0.58 & 0.87 & 1.16 & 1.14 & 1.71 & 2.28 & 1.62 & 2.03 & 3.57 & 3.57 & 8.92 & 11.90 & 6.91 & 13.53 & 18.91 & 50.8 & 53.4 & 56.0 \\
\hline Papua & 0.79 & 1.18 & 1.58 & 0.53 & 0.80 & 1.06 & 0.58 & 0.73 & 0.00 & 0.00 & 0.00 & 0.00 & 1.90 & 2.71 & 2.64 & 14.0 & 10.7 & 7.8 \\
\hline Total & 1.68 & 2.52 & 3.37 & 2.48 & 3.72 & 4.96 & 3.52 & 4.40 & 5.87 & 5.87 & 14.68 & 19.57 & 13.56 & 25.33 & 33.77 & & & \\
\hline
\end{tabular}

Percentage (\%) of each total C estimate is indicated in the last column. Detailed data by province are provided in Additional file 1: Tables 17-19

Table 8 Differences in medium peat carbon storage (GtC) between map sources $\left(\mathrm{GtC}_{\mathrm{MoA}}-\mathrm{GtC}_{\mathrm{wI}}\right)$ by depth class and island

\begin{tabular}{|c|c|c|c|c|c|c|}
\hline \multirow[t]{2}{*}{ Province } & \multicolumn{6}{|c|}{ Depth class } \\
\hline & $<50 \mathrm{~cm}$ & $50-100 \mathrm{~cm}$ & $100-200 \mathrm{~cm}$ & $>200 \mathrm{~cm}$ & Total & $\%$ \\
\hline Kalimantan & -0.03 & -0.32 & -0.01 & -0.18 & -0.55 & 10 \\
\hline Sumatra & 0.00 & 0.69 & -1.74 & -0.45 & -1.49 & 27 \\
\hline Papua & -0.03 & -1.44 & 0.11 & -2.07 & -3.42 & 63 \\
\hline Total & -0.06 & -1.07 & -1.63 & -2.70 & -5.46 & 100 \\
\hline
\end{tabular}

Depth classes $>200 \mathrm{~cm}$ were combined to allow comparison, detailed data by province and for depth classes $>200 \mathrm{~cm}$ are provided in Additional file 1: Tables $11-13$

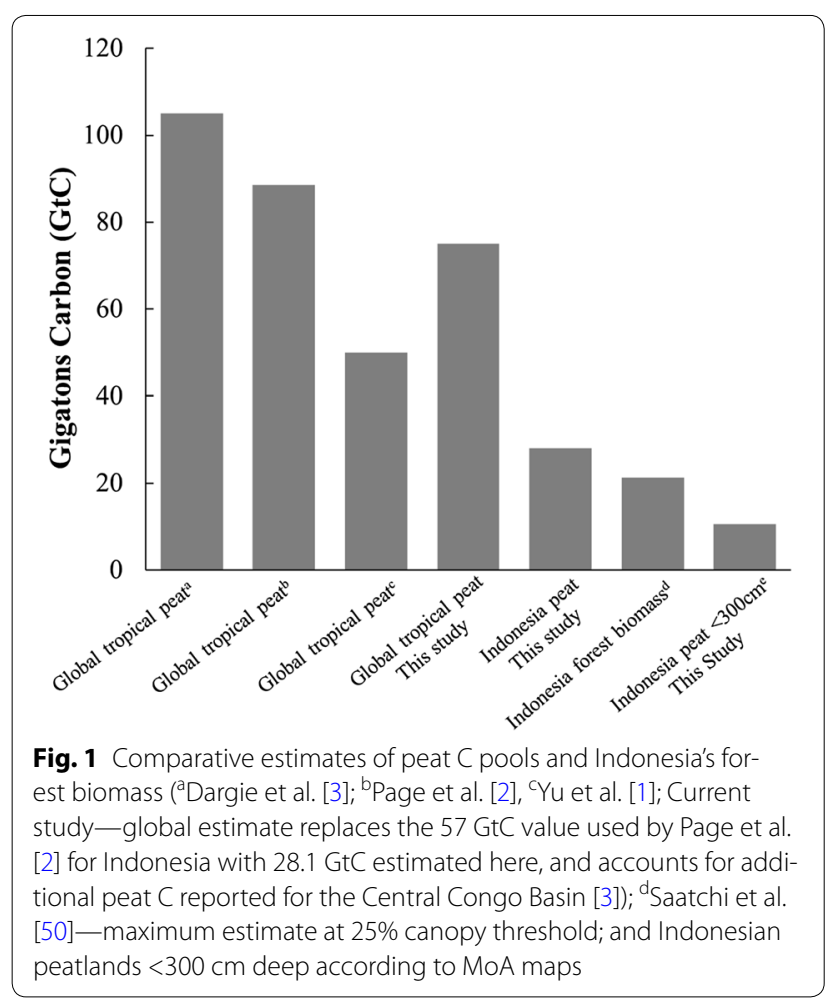

map estimate). The wide range of these estimates reflects the current state of uncertainty in Indonesia's peatland maps, both in areal extent and volume. The upper and lower bounds of the peatland carbon estimates are probably substantial over- and underestimates, as they assume all peatlands within a given depth interval are at the upper or lower value of the interval, and values represent the minimum and maximum spatial extent of peatlands included on the MoA and WI maps. It is important to note that our suggested value of $28.1 \mathrm{GtC}$ is the midpoint of the two best estimates from each map source, each with a wide range of uncertainty. Additional field data are needed, particularly for Papua provinces, to better constrain the estimate of Indonesia's total peat $C$ store.

Our assessment of Indonesia's peat carbon store revises the current global estimate of tropical peat carbon from 105 to 75 GtC (Fig. 1; [3]). The revised global estimate is almost the midpoint between the $50 \mathrm{GtC}$ provided by $\mathrm{Yu}$ et al. [1], who used a carbon accumulation model and peatland distribution maps (Fig. 1), and 105 GtC suggested by Dargie et al. [3], who revised Page et al's [2] global estimate to include new data from the central Congo Basin. However, the peatland distribution map for Indonesia used by Yu et al. [1] was digitized from a descriptive figure provided by Page et al. [46], and is therefore a coarse representation of a large proportion of the total tropical peatland area. Using a refined modeling approach, Dommain et al. [9] quantified carbon stocks of West Indonesia (Sumatra and Kalimantan) at about $23 \mathrm{GtC}$, close to our $24.7 \mathrm{GtC}$ medium estimate using the WI maps for the same area. The agreement 
between these values is expected, as Dommain et al. [9], used regionally specific values for carbon accumulation and the WI maps of peat distribution and depth in their analysis. Our carbon storage estimate for West Indonesia using the MoA maps is $22.6 \mathrm{GtC}$, remarkably similar to the $23 \mathrm{GtC}$ reported by Dommain et al. [9]. However given the $1,758,934$ ha difference in peat area between the MoA and WI maps for West Indonesia, it is likely that the peat volume modeled by Dommain et al. [9] was lower than the volumes obtained from WI maps for the same area, rather than suggesting higher accuracy of the MoA peat distribution maps.

Our medium carbon storage value for the WI maps is about $6.4 \mathrm{GtC}$ lower than the total provided by Wahyunto et al. [5-7], despite using the same data for peat extent and depth. This difference is attributed to higher carbon density values used by Wahyunto et al. [5-7]. For example, $C_{d}$ values used by Wahyunto et al. [5] for hemic and sapric peat in Sumatra were 82.5 and $125.6 \mathrm{~kg} \mathrm{C} / \mathrm{m}^{3}$, considerably higher than values typically found in the literature. The $C_{d}$ values used by Wahyunto et al. [5-7] reflect the high values of representative bulk density for hemic and sapric peat, ranging from 170 to $280 \mathrm{~kg} / \mathrm{m}^{3}$. Although carbon density of Indonesian peatlands varies considerably with bulk density and $C$ content [15], we assumed $C_{d}$ values ranging from $54.5 \mathrm{~kg} \mathrm{C} / \mathrm{m}^{3}$ for Jambi, Sumatra to $69.76 \mathrm{~kg} \mathrm{C} / \mathrm{m}^{3}$ for Riau, Sumatra based on published regional studies (Table 1). Where regional $C_{d}$ values were unavailable, peatlands were assigned an average value of $65.1 \mathrm{~kg} \mathrm{C} / \mathrm{m}^{3}$. Although these values are higher than the assumed $50.4 \mathrm{~kg} \mathrm{C} / \mathrm{m}^{3}$ used by Page et al. [2], and $58.0 \mathrm{~kg} \mathrm{C} / \mathrm{m}^{3}$ used by Jaenicke et al. [13], $C_{d}$ values assumed here are much lower than those used by Wahyunto et al. [5-7].

Indonesia's peatland area is estimated to be between 14.9 Mha (MoA) and 20.9 Mha (WI). Overall differences in peatland area, volume and carbon storage between map sources are largely due to inconsistencies in the area and depth of peatland mapped in Papua province, which accounts for $71 \%$ of the difference in area, $62 \%$ of the difference in volume, and $63 \%$ of the difference in carbon storage. The expansive southern coastal plain of Papua contains one of the largest intact wetland forests in the world. Systematic survey of peat presence and its thickness is hindered by the logistical difficulties of accessing remote areas to acquire ground based data. Moreover, traversing the mosaic of mangrove, pandan marsh, Sago palm and swamp forests is costly, inefficient, and physically challenging. These factors preclude a rigorous systematic peatland survey of southern Papua, thereby introducing uncertainties in peatland maps. Although Papua accounts for the largest difference in peat volume and carbon storage, there are consistently fewer peatlands delineated on the MoA maps for all provinces except West Papua. A systematic revision of Indonesia's peatland map based on reliable ground based data is necessary to assess peat volume and carbon storage with higher accuracy. Because of the inconsistencies between peat maps, they should be used for reference only. Intensive site-based surveys and peat evaluation at local or project levels are essential for spatial planning or land management purposes due to the uncertainties of peat presence and thickness at the project scale.

According to MoA maps, $80 \%$ of Indonesia's peatlands are less than $300 \mathrm{~cm}$ deep and contain between 7.7 and $14.2 \mathrm{GtC}$, with a best estimate of $10.6 \mathrm{GtC}$, or $42 \%$ of Indonesia's total peat carbon store. The WI maps indicate a similar percentage $(83 \%)$ of peatlands mapped less than $400 \mathrm{~cm}$ deep, storing about $16.0 \mathrm{GtC}$. These estimates have significant implications for future carbon emissions and the fate of peatlands in shallower depth classes. According to Indonesian law (Presidential Decree 32/1990 and Government Regulation No 26/2008) land use conversion is allowable on peatland up to $300 \mathrm{~cm}$ deep. These laws stipulate that peat forests in the depth class $>300 \mathrm{~cm}$ designated on the MoA maps are not to be drained and converted to other land uses and hydrological functions are to be retained. Therefore, assuming drainage persists to the base of the peat layer, $10.6 \mathrm{GtC}$ are vulnerable to losses from land conversion, peat oxidation, and burning; equivalent to about 12 years of all global emissions from land use change at current rates (0.9 GtC year ${ }^{-1}$; [49]). This estimate is highly conservative, as it assumes the area of peatlands $<300 \mathrm{~cm}$ is not underestimated, $100 \%$ compliance with environmental law, and does not consider biomass losses and ongoing losses from peatland $>300 \mathrm{~cm}$ deep converted to other land uses prior to 1990. Furthermore, additional largescale $\mathrm{C}$ losses resulting from uncontrolled peat burning or wildfire spreading into peat areas $>300 \mathrm{~cm}$ deep are not included in the estimate. Additional losses could also occur if dry seasons are extended or are more severe due to climate change [50]. Although the calculation does not account for the preservation of peatlands $<300 \mathrm{~cm}$ deep within protected areas, it is unlikely that the relatively small volume of protected shallow peat offsets carbon losses of converted or degraded peatlands $>300 \mathrm{~cm}$ deep. In addition to large scale GHG emissions, the potential legal conversion of $80 \%$ of Indonesia's peatland area-the proportion of peatland mapped $<300 \mathrm{~cm}$-is concerning considering the potential losses of biodiversity and associated ecosystem services. The potential loss of this carbon stock in "shallow" peat is equivalent to about half of all Indonesian forest biomass, further illustrating that accurate peat mapping, particularly of the $300 \mathrm{~cm}$ threshold and responsible peatland management is imperative 
to Indonesia's efforts to reduce greenhouse gas emissions from the LULUCF sector.

\section{Conclusions}

According to our assessment, Indonesia's total peat carbon store lies somewhere between 13.6 and $40.5 \mathrm{GtC}$, with a best estimate of $28.1 \mathrm{GtC}$, the midpoint of medium carbon storage values calculated from WI and MoA maps. The large range of peat carbon estimates reflects considerable differences in peat volume provided by the map sources. The large uncertainties of peat extent, volume and carbon storage in Papua provinces, where data are most lacking, contribute to most of the differences in peat carbon storage estimates between map sources. Therefore, a robust peat survey of southern Papua province would help resolve the current discrepancies between peat maps.

Although lower than previous estimates, the $28.1 \mathrm{GtC}$ approximation of Indonesia's peatland carbon stocks presented here does not diminish the significance of Indonesia's peat carbon storage at national and global scales (Fig. 1). Our estimate of peat carbon storage exceeds the 21.6 GtC maximum estimated carbon stock in aboveand belowground biomass of all Indonesian forests by $30 \%$ [51], an observation similarly noted by Dommain et al. [9].

According to MoA national peat maps, approximately $80 \%$ of all Indonesian peatlands are less than $300 \mathrm{~cm}$ deep, and are thus allowable for conversion under current regulations. The past, ongoing and eventual conversion of these shallower peatlands could release approximately 10.6 $\mathrm{GtC}$ to the atmosphere assuming total peat loss, significantly contributing to global climate change [50]. Considering the high uncertainties in peatland extent, volume and carbon storage revealed in this assessment of current maps, a systematic revision of Indonesia's peat maps to produce a single geospatial reference that is universally accepted would improve national peat carbon storage estimates and greatly benefit carbon cycle research, land use management and spatial planning.

\section{Additional file}

Additional file 1. Warren et al. (2017) an appraisal of Indonesia's immense peat carbon stock using national peatland maps: uncertainties and potential losses from conversion.

\section{Authors' contributions}

$\mathrm{MW}, \mathrm{KH}, \mathrm{JBK}, \mathrm{DM}$ and RK designed the study. MW analyzed data. MW and $\mathrm{KH}$ wrote the paper with input from JBK, DM and RK. All authors read approved the final manuscript.

\section{Author details}

${ }^{1}$ USDA Forest Service, Northern Research Station, 271 Mast Rd., Durham, NH 03824, USA. ${ }^{2}$ Center for International Forestry Research, CIFOR c/o Centro
Internacional de la Papa (CIP), Av. La Molina 1895, La Molina, Apdo postal 1558, 15024 Lima, Peru. ${ }^{3}$ Center for International Forestry Research, J. CIFOR, Situgede, Bogor 16115, Indonesia. ${ }^{4}$ Department of Fisheries and Wildlife, Oregon State University, 104 Nash Hall, Corvallis, OR 97331, USA. ${ }^{5}$ Department of Geophysics and Meteorology, Bogor Agricultural University, Kampus Darmaga, Bogor 16680, Indonesia. ${ }^{6}$ USDA Forest Service, Northern Research Station, 1831 Hwy 169 East, Grand Rapids, MN 55744, USA.

\section{Acknowledgements}

The authors wish to thank the USFS International Programs office and the Center for International Forestry Research for support and facilitation of this research.

\section{Competing interests \\ The authors declare that they have no competing interests.}

\section{Availability of data and materials}

Data for this study is available in references $[4-6,35]$. In addition, all data are summarized and provided as supplemental information.

\section{Funding}

This work was funded by the USAID's Sustainable Wetlands Adaptation and Mitigation Program (SWAMP), with additional support from the USAIDIndonesia Forest and Climate Support Program and US State Department's Peatlands, Forests, and Climate Partnership.

\section{Publisher's Note}

Springer Nature remains neutral with regard to jurisdictional claims in published maps and institutional affiliations.

Received: 12 January 2017 Accepted: 9 May 2017

Published online: 19 May 2017

\section{References}

1. Yu Z, Loisel J, Brosseau D, Beilman D, Hunt S. Global peatland dynamics since the Last Glacial Maximum. Geophys Res Lett. 2010;37(13):L13402.

2. Page S, Rieley J, Banks C. Global and regional importance of the tropical peatland carbon pool. Glob Change Biol. 2011;17(2):798-818.

3. Dargie GC, Lewis SL, Lawson IT, Mitchard ETA, Page SE, Bocko YE, Ifo SA. Age, extent and carbon storage of the Central Congo Basin peatland complex. Nature. 2017. doi:10.1038/nature21048.

4. RePpProt (1988-1990) A National Overview from the Regional Physical Planning Programme for Transmigration. UK Overseas Development Administration and Directorate Bina Program, Ministry of Transmigration, Jakarta.

5. Wahyunto, Heryanto B, Bekti H, Widiastuti F. Maps of peatland distribution, area and carbon content in Papua, 2000-2001. Wetlands International-Indonesia Programme \& Wildlife Habitat Canada (WHC), Bogor. 2006.

6. Wahyunto, Ritung S, Subagjo H. Maps of area of peatland distribution and carbon content in Sumatra, 1990-2002. Wetlands International-Indonesia Programme \& Wildlife Habitat Canada (WHC), Bogor. 2003.

7. Wahyunto, Ritung S, Suparto, Subagjo H. Maps of area of peatland distribution and carbon content in Kalimantan, 2000-2002. Wetlands International-Indonesia Programme \& Wildlife Habitat Canada (WHC), Bogor. 2004.

8. Anshari G, Peter Kershaw A Van Der Kaars S, Jacobsen G. Environmental change and peatland forest dynamics in the Lake Sentarum area, West Kalimantan Indonesia. J Quat Sci. 2004;19(7):637-55.

9. Dommain R, Couwenberg J, Glaser P, Joosten H, Suryadiputra I. Carbon storage and release in Indonesian peatlands since the last deglaciation. Quat Sci Rev. 2014;97:1-32.

10. Hergoualc'h K, Verchot L. Stocks and fluxes of carbon associated with land use change in Southeast Asian tropical peatlands: a review. Glob Biogeochem Cycles. 2011. doi:10.1029/2009GB003718.

11. Yule C, Gomez L. Leaf litter decomposition in a tropical peat swamp forest in Peninsular Malaysia. Wetl Ecol Manage. 2008;17(3):231-41. 
12. Kurnianto S, Warren M, Talbot J, Kauffman B, Murdiyarso D, Frolking S. Carbon accumulation of tropical peatlands over millennia: a modeling approach. Glob Change Biol. 2014;21(1):431-44.

13. Jaenicke J, Rieley J, Mott C, Kimman P, Siegert F. Determination of the amount of carbon stored in Indonesian peatlands. Geoderma. 2008;147(3-4):151-8.

14. Murdiyarso D, Donato D, Kauffman JB, Kurnianto S, Stidham M, Kanninen, M. Carbon storage in mangrove and peatland ecosystems, Working Paper 48, Center for International Forestry Research, Bogor, Indonesia, 2009.

15. Warren M, Kauffman J, Murdiyarso D, Anshari G, Hergoualc'h K, Kurnianto $\mathrm{S}$, et al. A cost-efficient method to assess carbon stocks in tropical peat soil. Biogeosci Discuss. 2012;9(6):7049-71.

16. Aalde H, Gytarsky M, Krug T, Kurz WA, et al. Chapter 4: Forestland. In: Eggleston HS, Buendia L, Miwa K, Ngara T, Tanabe K, editors. 2006 IPCC Guidelines for National Greenhouse Gas Inventories. Japan: IGES; 2006. p. 4.53.

17. Cheyne S, Macdonald D. Wild felid diversity and activity patterns in Sabangau peat-swamp forest, Indonesian Borneo. Oryx. 2011;45(01):119-24.

18. Wich S, Meijaard E, Marshall A, Husson S, Ancrenaz M, Lacy R, et al. Distribution and conservation status of the orang-utan (Pongo spp.) on Borneo and Sumatra: how many remain? Oryx. 2008:42(03):329-39.

19. Posa M, Wijedasa L, Corlett R. Biodiversity and conservation of tropical peat swamp forests. Bioscience. 2011;61(1):49-57.

20. Nowak K. Mangrove and peat swamp forests: refuge habitats for primates and felids. Folia Primatol. 2012;83(3-6):361-76.

21. Langner A, Miettinen J, Siegert F. Land cover change 2002-2005 in Borneo and the role of fire derived from MODIS imagery. Glob Change Biol. 2007:13(11):2329-40.

22. Miettinen J, Shi C, Liew SC. Land cover distribution in the peatlands of Peninsular Malaysia, Sumatra and Borneo in 2015 with changes since 1990. Glob Ecol Conserv. 2016;6:67-78.

23. Margono B, Potapov P, Turubanova S, Stolle F, Hansen M. Primary forest cover loss in Indonesia over 2000-2012. Nat Clim Change. 2014;4(8):730-5.

24. Miettinen J, Shi C, Liew S. Deforestation rates in insular Southeast Asia between 2000 and 2010. Glob Change Biol. 2011;17(7):2261-70.

25. Miettinen J, Hooijer A, Shi C, Tollenaar D, Vernimmen R, Liew S, et al. Extent of industrial plantations on Southeast Asian peatlands in 2010 with analysis of historical expansion and future projections. GCB Bioenerg. 2012;4(6):908-18

26. Gaveau D, Salim M, Hergoualc'h K, Locatelli B, Sloan S, Wooster M, et al. Major atmospheric emissions from peat fires in Southeast Asia during non-drought years: evidence from the 2013 Sumatran fires. Sci Rep. 2014;4:6112.

27. Couwenberg J, Dommain R, Joosten H. Greenhouse gas fluxes from tropical peatlands in south-east Asia. Glob Change Biol. 2010;16(6):1715-32.

28. Jauhiainen J, Hooijer A, Page SE. Carbon dioxide emissions from an Acacia plantation on peatland in Sumatra, Indonesia. Biogeosciences. 2012;9:617-30.

29. Jauhiainen J, Kerojoki O, Silvennoinen H, Limin S, Vasander H. Heterotrophic respiration in drained tropical peat is greatly affected by temperature - a passive ecosystem cooling experiment. Environ Res Lett. 2014;9(10):105013.

30. Comeau L, Hergoualc'h K, Hartill J, Smith J, Verchot L, Peak D, et al. How do the heterotrophic and the total soil respiration of an oil palm plantation on peat respond to nitrogen fertilizer application? Geoderma. 2016;268:41-51.

31. Drösler M, Verchot LV, Freibauer A, et al. editors. Supplement to the 2006 guidelines for national greenhouse gas inventories: Wetlands. Switzerland: IPCC; 2013.

32. Hergoualc'h K, Verchot L. Greenhouse gas emission factors for land use and land-use change in Southeast Asian peatlands. Mitig Adapt Strateg Glob Change. 2013;19(6):789-807.

33. PEACE. Indonesia and climate change: current status and policies. Jakarta, Indonesia, 2007.
34. Dewen Nasional Perubahan Iklim, Indonesia (DNPI). Indonesia's greenhouse gas abatement cost curve. National Council on Climate Change. Jakarta Indonesia, 2010

35. Dommain R, Couwenberg J, Joosten H. Development and carbon sequestration of tropical peat domes in south-east Asia: links to postglacial sea-level changes and Holocene climate variability. Quat Sci Rev. 2011:30(7-8):999-1010.

36. Haryono, Sarwani M, Ritung S, et al. Peatland Map of Indonesia. Center for Research and Development of Agricultural Land Resources, Agricultural Research and Development Agency, Indonesia Ministry of Agriculture. Bogor, Indonesia, 2011

37. Miettinen J, Liew S. Degradation and development of peatlands in Peninsular Malaysia and in the islands of Sumatra and Borneo since 1990. Land Degrad Dev. 2010;21:285-96.

38. Miettinen J, Shi C, Liew S. Two decades of destruction in Southeast Asia's peat swamp forests. Front Ecol Environ. 2012;10(3):124-8.

39. Miettinen J, Shi C, Tan W, Liew S. 2010 land cover map of insular Southeast Asia in 250-m spatial resolution. Remote Sens Lett. 2012;3(1):11-20.

40. Ballhorn U, Siegert F, Mason M, Limin S. Derivation of burn scar depths and estimation of carbon emissions with LIDAR in Indonesian peatlands. Proc Natl Acad Sci. 2009;106(50):21213-8.

41. Draper F, Roucoux K, Lawson I, Mitchard E, Honorio Coronado E Lähteenoja $\mathrm{O}$, et al. The distribution and amount of carbon in the largest peatland complex in Amazonia. Environ Res Lett. 2014;9(12):124017.

42. Nelson DW, Sommers LE. Total carbon, organic carbon, and organic matter. In: Page AL, Miller RH, Kenney, DR, editors. Methods of soil analysis: chemical and microbial properties. ASA Monograph 9, Madison: American Society of Agronomy; 1982

43. Farmer J, Matthews R, Smith P, Langan C, Hergoualc'h K, Verchot L, et al. Comparison of methods for quantifying soil carbon in tropical peats. Geoderma. 2014:214-215:177-83.

44. Neuzil SG. Onset and rate of peat and carbon accumulation in four domed ombrogenous peat deposits, Indonesia. In: Rieley JO, Page SE, editors. Proceedings of the International Symposium on Biodiversity, Environmental Importance, and Sustainability of Tropical Peat and Peatlands, Palangka Raya, Central Kalimantan, Indonesia, Cardigan: Samara Publishing Ltd.;1997.

45. Anshari GZ, Afifudin M, Nuriman M, Gusmayanti E, Arianie L, Susana R, Nusantara RW, Sugardjito J, Rafiastanto A. Drainage and land use impacts on changes in selected peat properties and peat degradation in West Kalimantan Province, Indonesia. Biogeosciences. 2010;7:3403-19.

46. Page S, Wüst R, Weiss D, Rieley J, Shotyk W, Limin S. A record of Late Pleistocene and Holocene carbon accumulation and climate change from an equatorial peat bog (Kalimantan, Indonesia): implications for past, present and future carbon dynamics. J Quat Sci. 2004;19(7):625-35.

47. Brady MA. Organic matter dynamics of coastal peat deposits in Sumatra, Indonesia, PhD. Vancouver Canada: University of British Columbia; 1997.

48. Hooijer, A, Vernimmen, R. Peatland maps for Indonesia. Including accuracy assessment and recommendations for improvement, elevation mapping and evaluation of future flood risk. Quick Assessment and Nationwide Screening (QANS) of Peat and Lowland Resources and Action Planning for the Implementation of a National Lowland StrategyPVW3A10002. 2013; Agentschap NL 6201068 QANS Lowland Development, for Government of Indonesia and Partners for Water (Netherlands).

49. Le Quéré C, Moriarty Andrew RM, et al. Global carbon budget 2014. Earth Syst Sci Data Discuss. 2014;7(2):521-610.

50. Warren M, Frolking S, Dai Z, Kurnianto S. Impacts of land use, restoration, and climate change on tropical peat carbon stocks in the twenty-first century: implications for climate mitigation. Mitig Adapt Strateg Glob Change. 2016. doi:10.1007/s11027-016-9712-1.

51. Saatchi S, Harris N, Brown S, Lefsky M, Mitchard E, Salas W, et al. Benchmark map of forest carbon stocks in tropical regions across three continents. Proc Natl Acad Sci. 2011;108(24):9899-904. 